\title{
Two-component self-assemblies: investigation of a synergy between bis-urea stickers
}

\author{
Emilie Ressouche, ${ }^{\dagger}$ Sandrine Pensec, ${ }^{\dagger}$ Benjamin Isare, ${ }^{\dagger}$ Jacques Jestin $^{\ddagger}{ }^{\ddagger}$ and Laurent \\ Bouteiller $^{* \dagger}$ \\ † Sorbonne Universités, UPMC Univ Paris o6, CNRS, Institut Parisien de Chimie Moléculaire, Equipe \\ Chimie des Polymères, 4 Place Jussieu, F-75005 Paris, France \\ ${ }^{\ddagger}$ Laboratoire Léon Brillouin, UMR 12 CNRS-CEA, 91191 Gif-sur-Yvette Cedex, France
}

\section{SUPPORTING INFORMATION}

\section{Synthesis}

$\mathbf{M}_{\mathbf{P I B}}$. The synthesis of $\mathbf{M}_{\mathbf{P I B}}$ was adapted from reference 1. 2,4,6-trimethyl-1,3phenylenediisocyanate (Aldrich 5g , $24.7 \mathrm{mmol}, 1 \mathrm{eq}$ ) was dissolved into dry dichloromethane $(200 \mathrm{~mL})$ under inert atmosphere, and the mixture was transferred via a cannula into a stirred solution of amino-terminated PIB (Kerocom PIBA, BASF, 118.5 g, 60 $\%$ in solution in hydrocarbon, about 2 eq) at RT under inert atmosphere. The reaction was stirred overnight at RT, under inert atmosphere. A viscous colorless liquid was obtained, and precipitated dropwise twice into stirred ethyl acetate $(1 \mathrm{~L})$. After settling, a colorless oil was collected with a spatula and dried under vacuum $\left(10^{-6}\right.$ bar $)$ at $60^{\circ} \mathrm{C}(43 \mathrm{~g}, 75 \%)$.

Size exclusion chromatography: $M_{n}=2800 \mathrm{~g} \cdot \mathrm{mol}^{-1}, \mathrm{M}_{\mathrm{w}} / \mathrm{M}_{\mathrm{n}}=1.30$ (tetrahydrofurane eluent; polystyrene calibration).

${ }^{1} \mathbf{H}$ NMR $\left(500 \mathrm{MHz}, \mathrm{CDCl}_{3}-\mathrm{DMSO}_{6}\right) \delta(\mathrm{ppm}): 0.9-1.4\left(\mathrm{~m}, 297 \mathrm{H},\left(\mathrm{CH}_{3}\right)_{3}-\mathrm{C},\left(\mathrm{CH}_{\mathbf{2}^{-}}\right.\right.$ $\left.\left.\mathrm{C}\left(\mathrm{CH}_{3}\right)_{2}\right)_{\mathrm{n}}, \mathrm{CH}_{2}-\mathrm{CH}\left(\mathrm{CH}_{3}\right)-\mathrm{CH}_{2}\right), 2.04$ (s, 3H, $\mathrm{CH}_{3}-\mathrm{Ar}$ ), 2.09 (s, 6H, CH $\mathbf{H}_{3}-\mathrm{Ar}$ ), 3.08 (m, 4H, $\left.\mathrm{CH}_{2}-\mathrm{NH}\right), 5.25$ (s, 2H, $\left.\mathrm{CH}_{2}-\mathrm{NH}\right), 6.68$ (s, 2H, Ph-NH), 6.80 (s, 1H, ArH)

$\mathrm{DP}_{\mathrm{n}}=32.8, \mathrm{M}_{\mathrm{n}}=2330 \mathrm{~g} \cdot \mathrm{mol}^{-1}$

${ }^{13} \mathbf{C}$ NMR (JMOD, $\left.75 \mathrm{MHz}, \mathrm{CDCl}_{3}-\mathrm{DMSO}_{-}\right) \delta(\mathrm{ppm}): 18.40\left(\mathbf{C H}_{3}-\mathrm{Ar}\right), 22.87\left(\mathbf{C H}_{3}-\mathrm{Ar}\right)$, $27.48\left(\mathrm{CH}_{3}-\mathrm{CH}-\mathrm{CH}_{2}-\mathrm{CH}_{2}-\mathrm{NH}\right), 31.45\left(\mathrm{CH}_{3}-\mathbf{C H}-\mathrm{CH}_{2}-\mathrm{CH}_{2}-\mathrm{NH}\right), 35.95\left(\left(\left(\mathrm{CH}_{3}\right)_{2} \mathrm{C}-\mathrm{CH}_{2}\right)_{n}\right)$, $37.16\left(\left(\mathrm{CH}_{3}\right)_{3} \mathrm{C}\right), 40.81\left(\left(\left(\mathrm{CH}_{3}\right)_{2} \mathrm{C}-\mathrm{CH}_{2}\right)_{\mathrm{n}}-\mathbf{C H}_{2}\right), 42.88\left(\left(\left(\mathrm{CH}_{3}\right)_{2} \mathrm{C}-\mathrm{CH}_{2}\right)_{\mathrm{n}}\right), 58.19\left(\left(\mathrm{CH}_{3}\right)_{3} \mathbf{C}\right)$, $62.15\left(\mathrm{CH}_{3}-\mathrm{CH}-\mathrm{CH}_{2}-\mathrm{CH}_{2}-\mathrm{NH}\right), 63.59\left(\mathrm{CH}_{3}-\mathrm{CH}-\mathrm{CH}_{2}-\mathrm{CH}_{2}-\mathrm{NH}\right), 64.25\left(\left(\left(\mathrm{CH}_{3}\right)_{2} \mathbf{C}-\mathrm{CH}_{2}\right)_{\mathrm{n}}-\mathrm{CH}_{2}\right)$, 133.78 / 138.35 / 139.23 / 139.99 (Ar), 161.88 (C=O).

MALDI-TOF Dithranol/Na matrix: Found 1409.55; Calculated $\mathrm{M}_{2 \mathrm{n}=16}+\mathrm{Na}^{+}: 1409.34$ 
Table S1. Molar masses of the polymers used.

\begin{tabular}{ccc}
\hline polymer & $\mathrm{M}_{\mathrm{n}}(\mathrm{g} / \mathrm{mol})^{\mathrm{a}}$ & $\mathrm{M}_{\mathrm{w}} / \mathrm{M}_{\mathrm{n}}^{\mathrm{b}}$ \\
\hline $\mathbf{T}_{\mathbf{P I B}}$ & 2940 & 1.3 \\
$\mathbf{M}_{\mathbf{P I B}}$ & 2330 & 1.3 \\
$\mathbf{X}_{\mathbf{P I B}}$ & 2450 & 1.3
\end{tabular}

${ }^{\mathrm{a}}$ determined by ${ }^{1} \mathrm{H}$ NMR

${ }^{\mathrm{b}}$ determined by size exclusion chromatography

Table S2. Qualitative aspect of bis-urea solutions and their $1 / 1$ mixtures, at $10 \mathrm{mM}$ in toluene (F: fluid, V: viscous, G: gel).

\begin{tabular}{ccccc}
\hline & $\begin{array}{c}\text { no polymeric } \\
\text { bis-urea }\end{array}$ & $\mathbf{T}_{\mathbf{P I B}}$ & $\mathbf{M}_{\mathbf{P I B}}$ & $\mathbf{X}_{\mathbf{P I B}}$ \\
\hline no low molar & & $\mathrm{F}$ & $\mathrm{F}$ & $\mathrm{V}$ \\
mass bis-urea & $\mathrm{G}$ & $\mathrm{F}$ & $\mathrm{G}$ & $\mathrm{G}$ \\
$\mathbf{T}$ & $\mathrm{F}$ & $\mathrm{G}$ & $\mathrm{F}$ & $\mathrm{G}$ \\
$\mathbf{M}$ & $\mathrm{G}$ & $\mathrm{G}$ & $\mathrm{G}$ & $\mathrm{G}$ \\
$\mathbf{X}$ & & & &
\end{tabular}

Table S3. Ratio of FTIR bands $\left(A_{\max } / A_{\min }\right)$ for mixtures in toluene $(5 \mathrm{mM})$. Ratio values $\mathrm{A}_{\max } / \mathrm{A}_{\min } \leq 1.2$ (resp. $1.3 \leq \mathrm{A}_{\max } / \mathrm{A}_{\min }$ ) are characteristic for the filament (resp. tube) structure.

\begin{tabular}{ccccc}
\hline & $\begin{array}{c}\text { no polymeric } \\
\text { bis-urea }\end{array}$ & $\mathbf{T}_{\mathbf{P I B}}$ & $\mathbf{M}_{\mathbf{P I B}}$ & $\mathbf{X}_{\mathbf{P I B}}$ \\
\hline $\begin{array}{c}\text { no low molar } \\
\text { mass bis-urea }\end{array}$ & & 1.16 & 1.07 & 1.12 \\
$\mathbf{T}$ & 1.35 & 1.20 & 1.25 & 1.32 \\
$\mathbf{M}$ & 1.18 & 1.29 & 1.13 & 1.34 \\
$\mathbf{X}$ & 1.37 & 1.29 & 1.31 & 1.34 \\
\hline
\end{tabular}


Table S4. Overview of the previous work on related systems.

\begin{tabular}{ccc}
\hline bis-urea & solvent & reference \\
\hline $\mathbf{T}$ & toluene & 2 \\
$\mathbf{T}$ & dodecane, $\begin{array}{c}\text { heptane, cyclohexane, toluene, carbon } \\
\text { tetrachloride, chloroform }\end{array}$ & 3 \\
$\mathbf{T}$ & dodecane & 4 \\
$\mathbf{X}$ & toluene, chloroform & 5 \\
$\mathbf{T}_{\mathbf{P I B}}$ & heptane, toluene, chloroform & 1 \\
$\mathbf{T}_{\mathbf{P I B}}$ & cyclohexane & 6 \\
$\mathbf{T} / \mathbf{M}$ & toluene, chloroform & 7 \\
$\mathbf{T} / \mathbf{T}_{\mathbf{P I B}}$ & heptane & 1 \\
$\mathbf{M} / \mathbf{X}_{\mathbf{P I B}}$ & dodecane, toluene & 8 \\
\hline
\end{tabular}

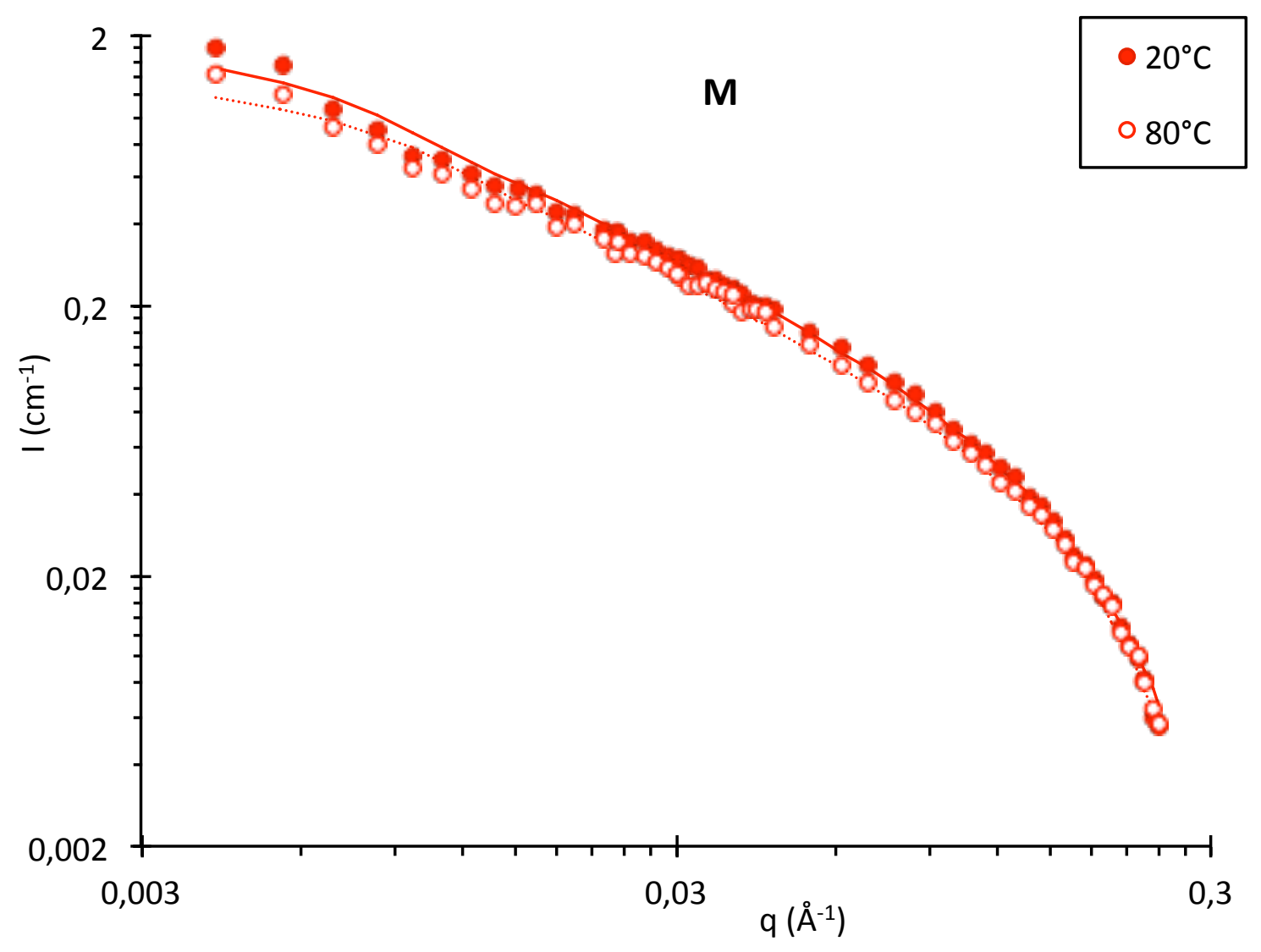

Figure S1. SANS intensity (I) versus scattering vector (q) for a solution of $\mathbf{M}$ at a concentration of $6 \mathrm{~g} / \mathrm{L}$ in toluene- $\mathrm{d}_{8}$, at $20^{\circ} \mathrm{C}$ (full symbol) and $80{ }^{\circ} \mathrm{C}$ (hollow symbol). The continuous line is the fit according to the form factor of a rod-like cylinder with an elliptical cross-section and homogeneous contrast. 


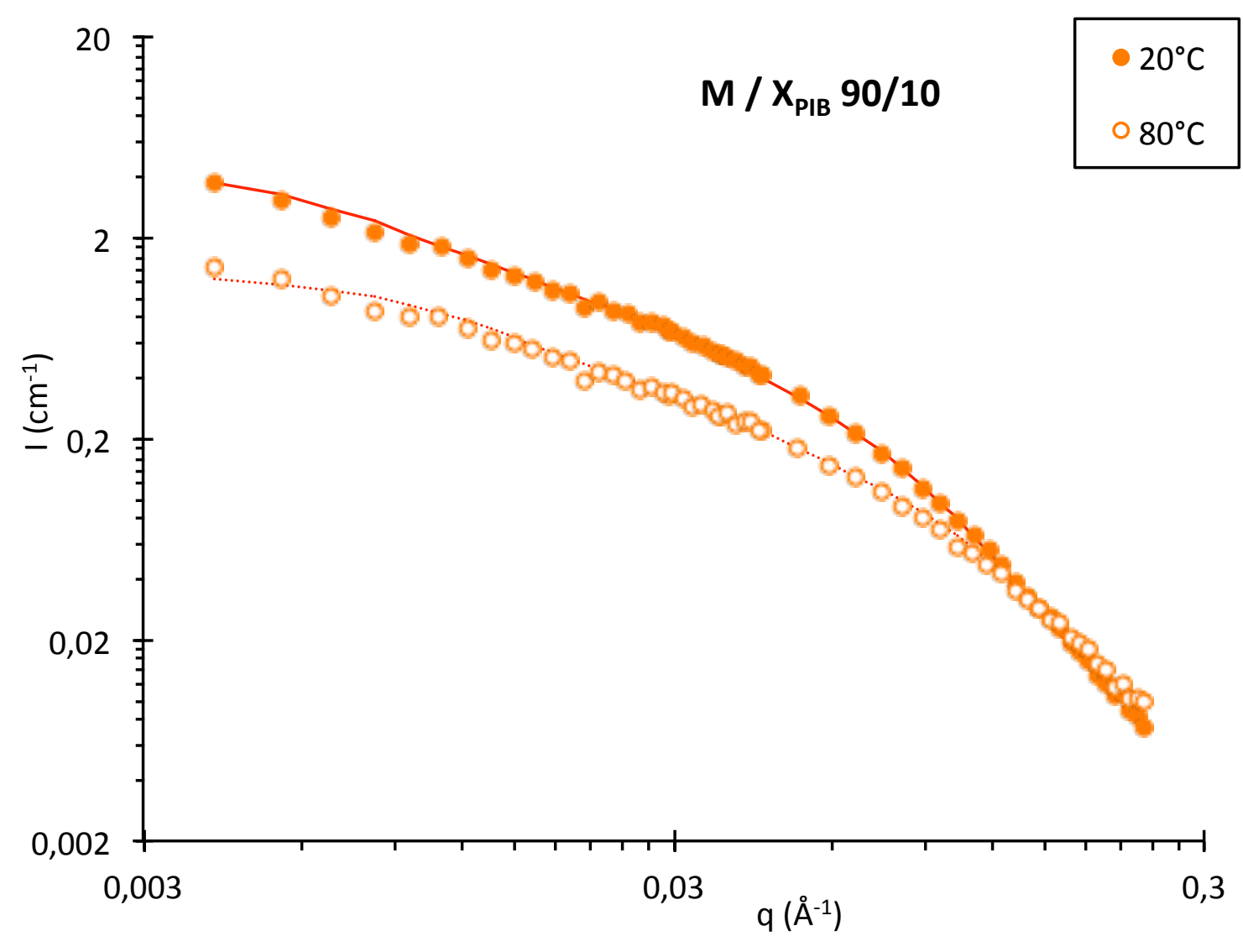

Figure S2. SANS intensity (I) versus scattering vector (q) for a solution of $\mathbf{M} / \mathbf{X}_{\mathbf{P I B}}$ 90/10 (molar fraction) at a concentration of $6 \mathrm{~g} / \mathrm{L}$ in toluene- $\mathrm{d}_{8}$, at $20^{\circ} \mathrm{C}$ (full symbol) and $80^{\circ} \mathrm{C}$ (hollow symbol). The continuous line is the fit according to the form factor of a rod-like cylinder with an elliptical cross-section and homogeneous contrast. 


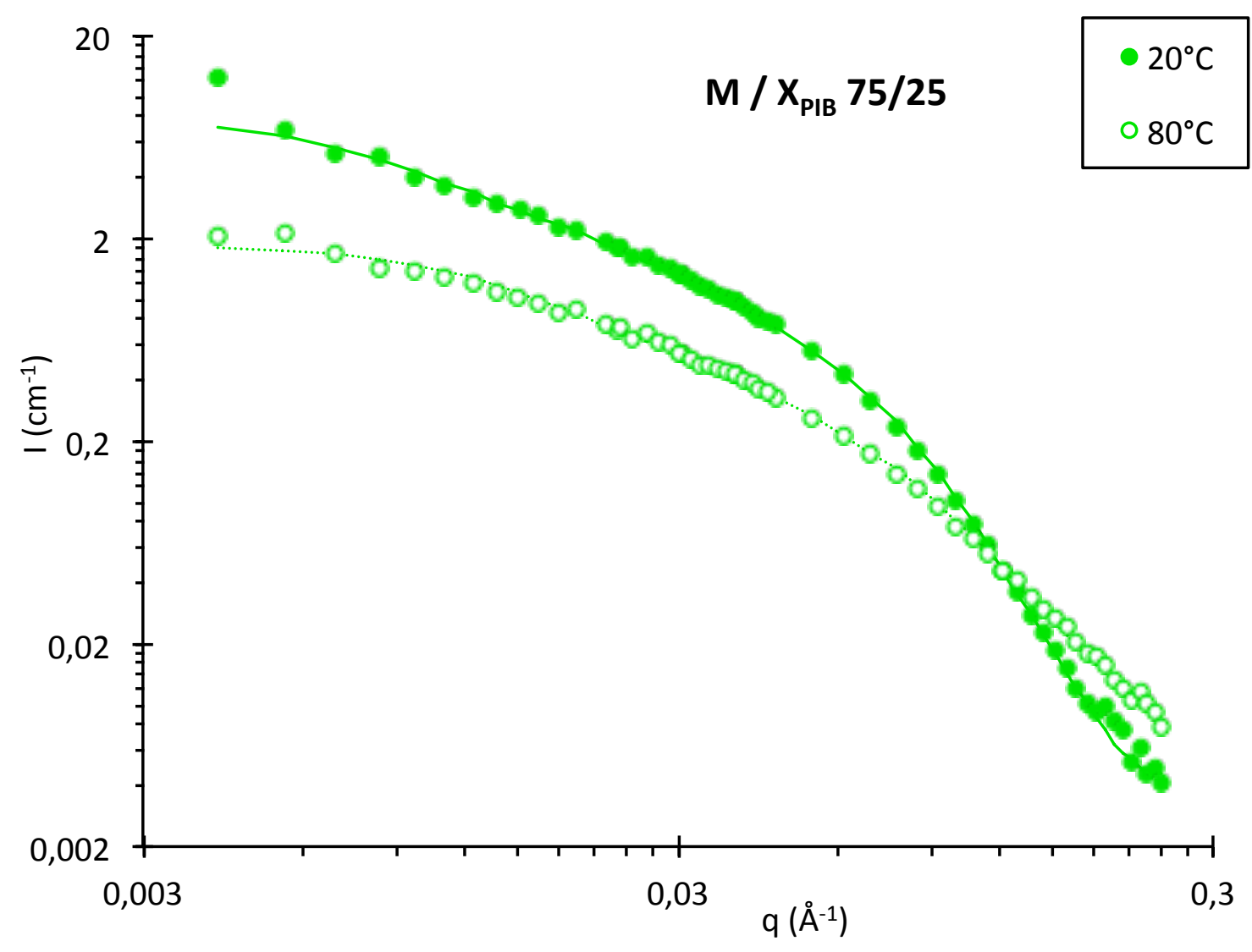

Figure S3. SANS intensity (I) versus scattering vector (q) for a solution of $\mathbf{M} / \mathbf{X}_{\mathbf{P I B}} 75 / 25$ (molar fraction) at a concentration of $6 \mathrm{~g} / \mathrm{L}$ in toluene- $\mathrm{d}_{8}$, at $20^{\circ} \mathrm{C}$ (full symbol) and $80{ }^{\circ} \mathrm{C}$ (hollow symbol). The continuous line is the fit according to the form factor of a rod-like cylinder with an elliptical cross-section and homogeneous contrast. 


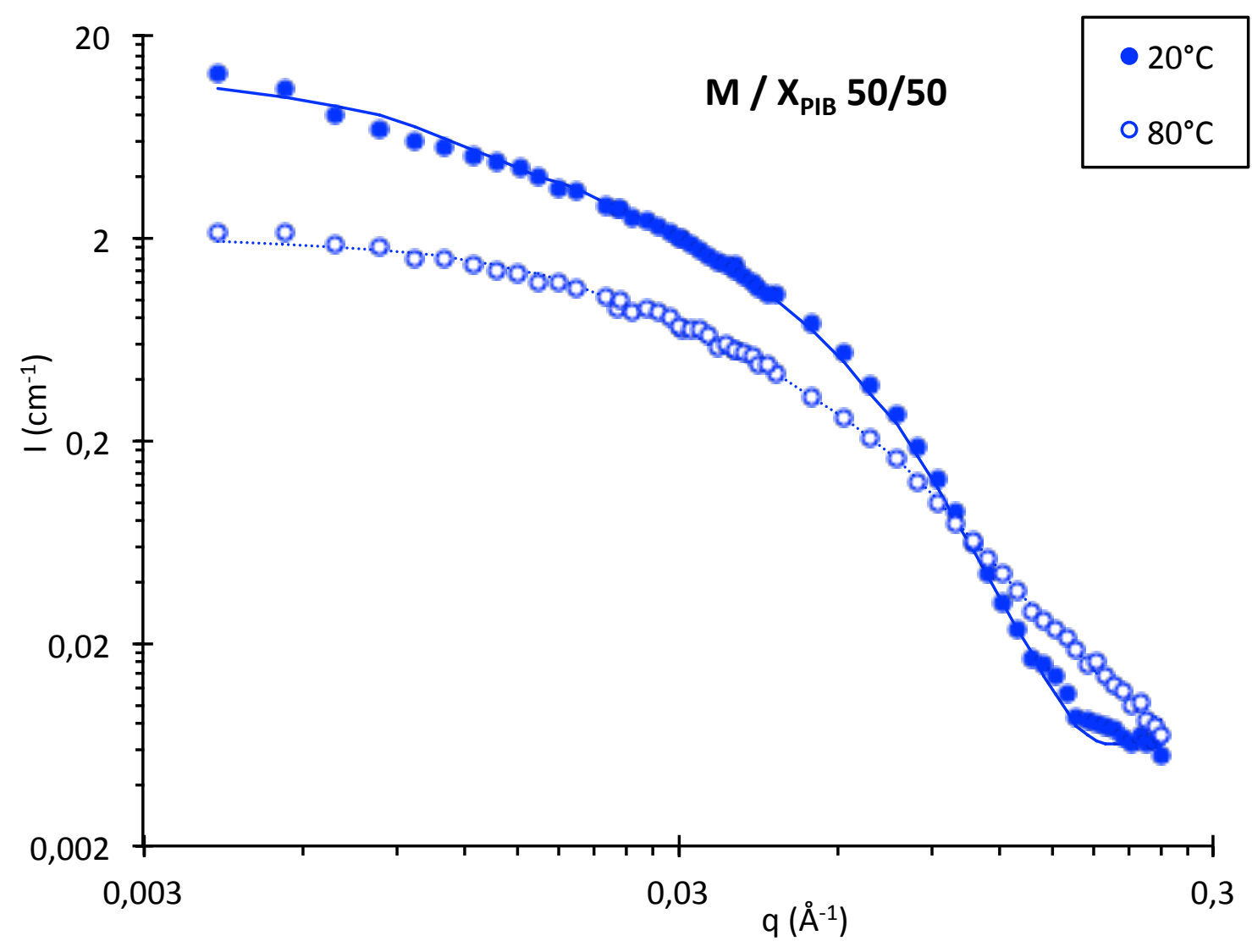

Figure S4. SANS intensity (I) versus scattering vector (q) for a solution of $\mathbf{M} / \mathbf{X}_{\mathbf{P I B}} 50 / 50$ (molar fraction) at a concentration of $6 \mathrm{~g} / \mathrm{L}$ in toluene- $\mathrm{d}_{8}$, at $20^{\circ} \mathrm{C}$ (full symbol) and $80{ }^{\circ} \mathrm{C}$ (hollow symbol). The continuous line is the fit according to the form factor of a rod-like cylinder with an elliptical cross-section and homogeneous contrast. 


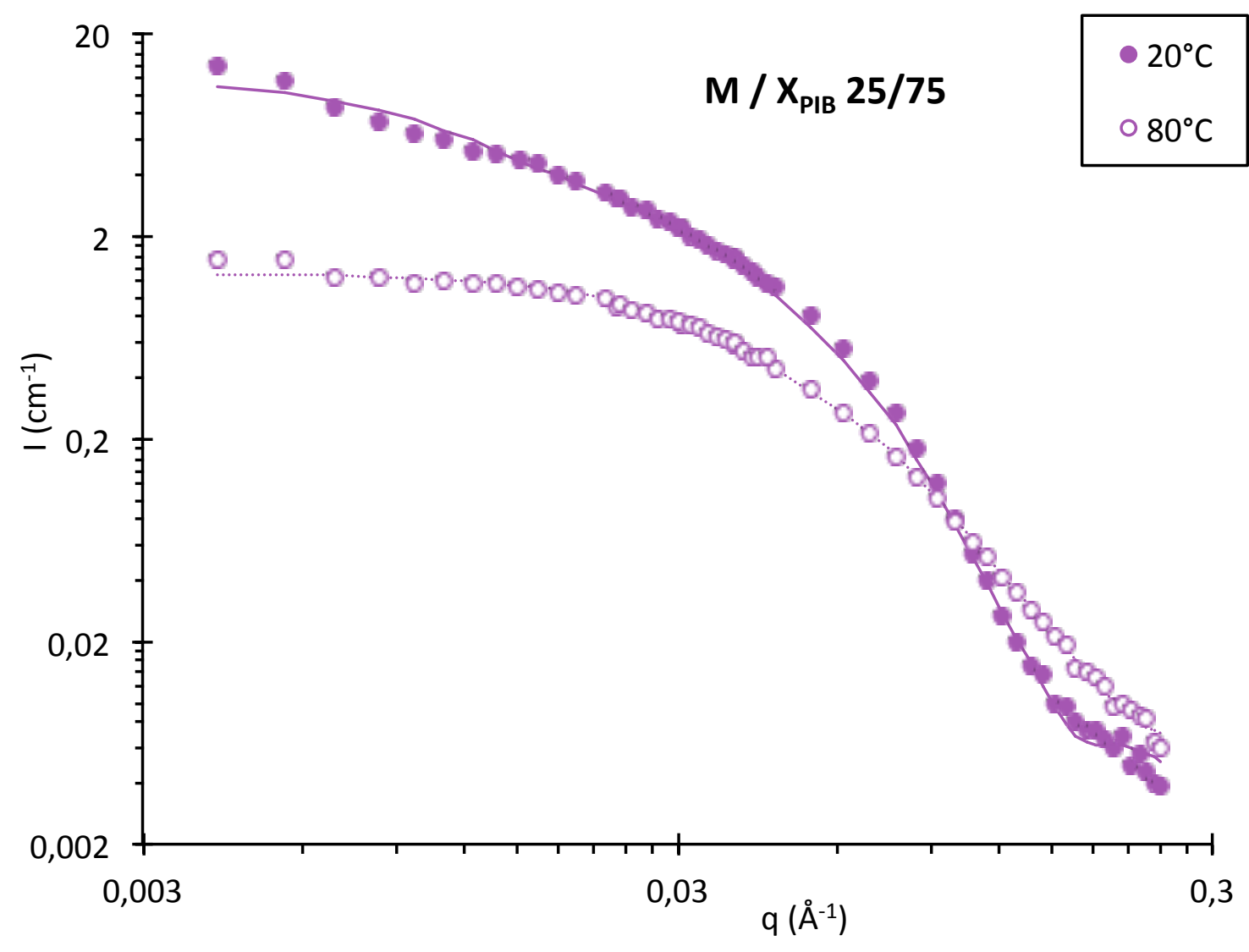

Figure S5. SANS intensity (I) versus scattering vector (q) for a solution of $\mathbf{M} / \mathbf{X}_{\mathbf{P I B}}$ 25/75 (molar fraction) at a concentration of $6 \mathrm{~g} / \mathrm{L}$ in toluene- $\mathrm{d}_{8}$, at $20^{\circ} \mathrm{C}$ (full symbol) and $80{ }^{\circ} \mathrm{C}$ (hollow symbol). The continuous line is the fit according to the form factor of a rod-like cylinder with an elliptical cross-section and homogeneous contrast. 


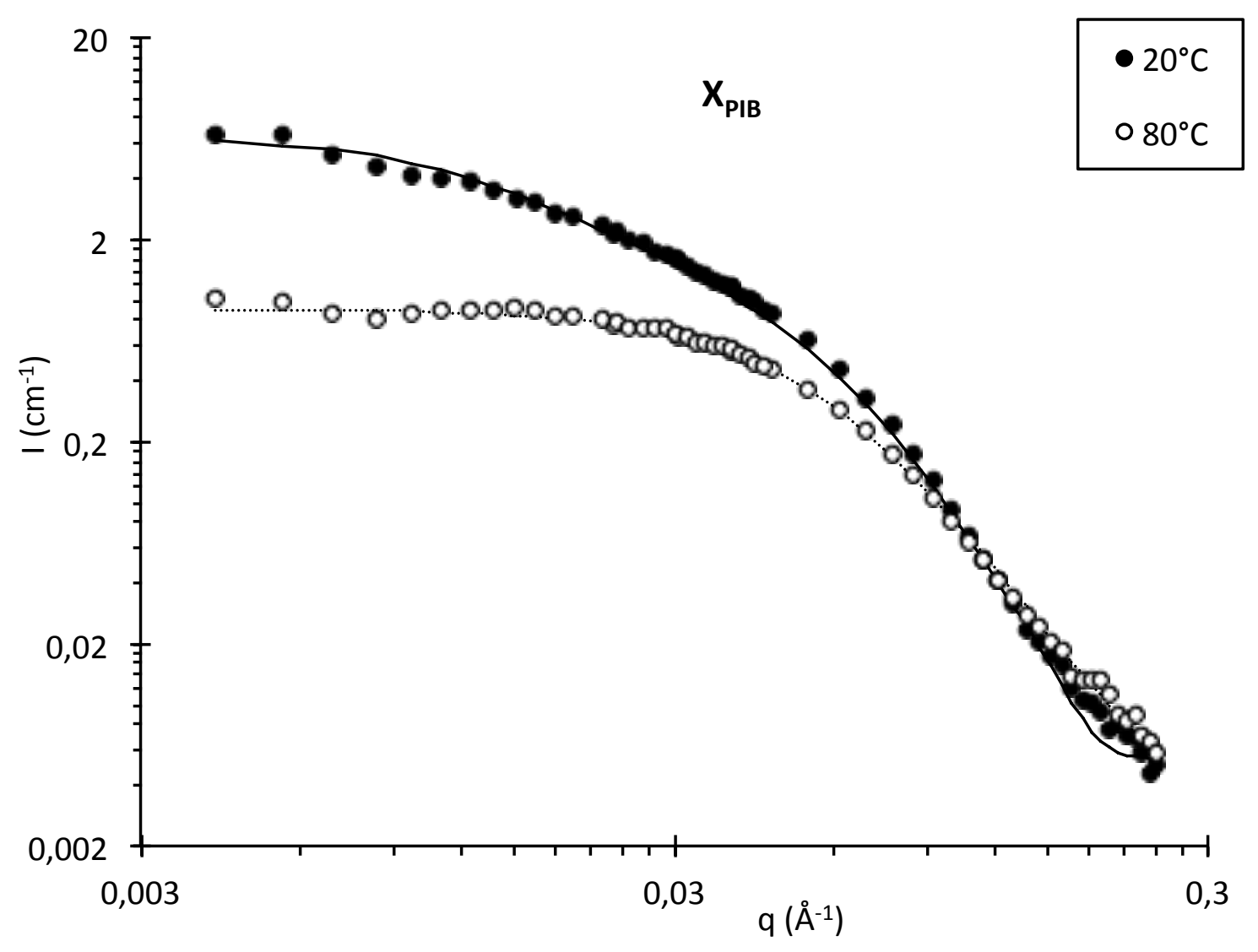

Figure S6. SANS intensity (I) versus scattering vector (q) for a solution of $\mathbf{X}_{\mathbf{P I B}}$ at a concentration of $6 \mathrm{~g} / \mathrm{L}$ in toluene- $\mathrm{d}_{8}$, at $20^{\circ} \mathrm{C}$ (full symbol) and $80{ }^{\circ} \mathrm{C}$ (hollow symbol). The continuous line is the fit according to the form factor of a rod-like cylinder with an elliptical cross-section and homogeneous contrast.

\section{References}

(1) Pensec, S.; Nouvel, N.; Guilleman, A.; Creton, C.; Boue, F.; Bouteiller, L. Self-Assembly in Solution of a Reversible Comb-Shaped Supramolecular Polymer. Macromolecules 2010, 43, 2529-2534

(2) Lortie, F.; Boileau, S.; Bouteiller, L.; Chassenieux, C.; Deme, B.; Ducouret, G.; Jalabert, M.; Laupretre, F.; Terech, P. Structural and Rheological Study of a Bis-Urea Based Reversible Polymer in an Apolar Solvent. Langmuir 2002, 18, 7218-7222

(3) Bouteiller, L.; Colombani, O.; Lortie, F.; Terech, P. Thickness Transition of a Rigid Supramolecular Polymer. J. Am. Chem. Soc. 2005, 127, 8893-8898

(4) Shikata, T.; Nishida, T.; Isare, B.; Linares, M.; Lazzaroni, R.; Bouteiller, L. Structure and Dynamics of a Bisurea-Based Supramolecular Polymer in N-Dodecane. J. Phys. Chem. B 2008, 112, 8459-8465

(5) Isare, B.; Pembouong, G.; Boue, F.; Bouteiller, L. Conformational Control of HydrogenBonded Aromatic Bis-Ureas. Langmuir 2012, 28, 7535-7541

(6) Catrouillet, S.; Fonteneau, C.; Bouteiller, L.; Delorme, N.; Nicol, E.; Nicolai, T.; Pensec, S.; Colombani, O. Competition Between Steric Hindrance and Hydrogen Bonding in the Formation of Supramolecular Bottle Brush Polymers. Macromolecules 2013, 46, 79117919 
(7) Isare, B.; Linares, M.; Lazzaroni, R.; Bouteiller, L. Engineering the Cavity of SelfAssembled Dynamic Nanotubes. J. Phys. Chem. B 2009, 113, 3360-3364

(8) Ressouche, E.; Pensec, S.; Isare, B.; Ducouret, G.; Bouteiller, L. Rational Design of Urea-Based Two-Component Organogelators. ACS Macro Lett. 2016, 5, 244-247 